\title{
Operational Assimilation of glider temperature and salinity in a mesoscale flow field: Eastern Mediterranean test case
}

\author{
Daniel R. Hayes ${ }^{1}$, Srdjan Dobricic ${ }^{2}$, Hezi Gildor ${ }^{3}$ \\ ${ }^{1}$ Oceanography Center, University of Cyprus, 1678 Nicosia, Cyprus \\ $5 \quad{ }^{2}$ Centro Euro-Mediterraneo sui Cambiamenti Climatici., Bologna, Italy \\ ${ }^{3}$ The Institute of Earth Sciences, The Hebrew University of Jerusalem, Jerusalem, Israel \\ Correspondence to: Daniel R. Hayes (dhayes@ucy.ac.cy)
}

\begin{abstract}
An operational data assimilation system for the Eastern Mediterranean is described and evaluated for a 6-month twin experiment. In the assimilative run, glider profiles of temperature and salinity are assimilated daily into a high

10 resolution ocean forecast, after an initial spin up of one week. In the control run, the same initial and boundary conditions are used to produce an operational forecast, but without assimilation of in situ data. While both runs were similar for most of the time and most of the domain, significant differences were found near the region of assimilation, particularly when the glider passed through the anticyclonic Cyprus eddy. Root mean square differences of the misfits between the temperature and salinity observations and the model background field at those locations (before any assimilation) were approximately $15 \%$

15 lower in the assimilative run. Improvements in the forecasting capability of surface currents were found, and would provide a significant improvement of predictive capacity for applications such as pollutant spreading or offshore operational safety.
\end{abstract}

Keywords: Gliders, Data Assimilation, Operational Oceanography, Cyprus Eddy

\section{Introduction}

20 Accurate operational forecast ocean models are crucial for numerous applications, such as oil spill predictions, search and rescue missions, and off-shore operations. In the case of semi-enclosed and densely populated basins, such as the Eastern Mediterranean, accurate predictions are especially needed as pollution can cause devastating damage, often to human or ecological health, as well as economic, in a relatively short time, e.g. if polluted water arrives near sensitive habitats, swimming beaches, desalination plants or aquaculture farms. Here it is shown how assimilation of glider data, an instrument that can be deployed at relatively short notice, or that can be used on a routine or ongoing basis, can significantly improve ocean forecasts in a small scale region, having in mind pollutant dispersion. Improved mesoscale and sub-mesoscale sampling and use in marine hazard applications (both possibly enhanced with data assimilation) were indeed identified as waysthe glider platform can contribute significantly to the Global Ocean Observing System (GOOS) (Liblik et al., 2016).

It was recognized a few decades ago that to improve the forecast skill of an operational ocean model, it is beneficial to 30 assimilate observed ocean state variables (see review by Edwards et al., 2015; Malanotte-Rizzoli and Tziperman, 1996). 
Ocean Sci. Discuss., doi:10.5194/os-2016-43, 2016

Manuscript under review for journal Ocean Sci.

Published: 28 June 2016

(c) Author(s) 2016. CC-BY 3.0 License.

Many forecast centers and institutions assimilate remotely-sensed observations such as sea level anomaly and/or sea surface temperature (SST). Assimilation is done in a hierarchy of models, from regional (e.g. Li et al., 2015) to global (e.g. Waters et al., 2015). In the Mediterranean Forecasting System flow model described by Tonani et al. (2008), for example, assimilation is done for SLA (Dobricic et al., 2012) and surface temperature is relaxed to remotely-sensed SST. For further improvement

5 in forecast skill, in situ data from the ocean depths are assimilated, typically temperature and salinity profiles collected by the network of ARGO floats or temperature profiles collected by expendable temperature probes (XBT) cast from ships of opportunity, as these are often available in near real time. It was shown by Dobricic et al. (2007) that assimilation of the temperature, salinity, and drift trajectory of freely-drifting and profiling ARGO floats increased the accuracy of the salinity analysis. Operational assimilation of four ARGO float trajectories at the same time as temperature and salinity (T-S) profiles,

10 and SLA was reported for the Mediterranean Forecasting System in Taillendier et al. (2010). It was shown that short-term analyses were improved with regard to boundary current intensity and width and water mass distributions. Nilsson et al. (2011) confirmed this technique of assimilating trajectories improves intermediate velocity fields (350 $\mathrm{m}$ depth) over the set of all available Mediterranean float trajectories. Especially relevant to the present study are efforts to assimilate glider data, such as Shulman et al. (2009) and Dobricic et al. (2010). Dobricic et al. (2010) showed that glider profiles of temperature

15 and salinity significantly increased the accuracy of the Mediterranean basin predictions of temperature, salinity, velocity, and surface elevation. Shulman et al. (2009) also reported model improvement when the data from 15 gliders were assimilated, effectively correcting errors introduced by inaccurate surface forcing in particular.

In this study, the methods above are taken further and the end-to-end construction and real-time operation of such a glider data assimilating system in the Eastern Levantine basin of the Mediterranean are demonstrated. The focus is on the

20 assimilation of an intense, small scale eddy and the straightforward impact of the assimilation in the vicinity of the assimilated data and for short forecasted time interval. This case is relevant in real-life applications, such as oil spills, when a quick response is needed, and an accurate prediction is crucial.

Ocean gliders, being such a versatile tool, have an important benefit over most other data sources. In many regions, there are few, if any, available in situ observations that can be assimilated, and those that exist may not be in the region of interest.

25 Ships provide excellent synoptic capability for regional studies, but cannot provide the horizontal resolution or the long-term presence required. In the case of freely drifting instruments, a particular feature may not be sampled suitably because the instrument(s) deployed in and around the feature drifts away or is grounded. It is possible, however, to use an autonomous, steerable platform, the ocean glider, to collect observations of specific, poorly simulated, processes over wide areas and long times in near real time for data assimilation. An overview of the history of gliders and their scientific applications over the 30 full range of scales is given by Rudnick (2016). Besides providing a unique niche in time and space, gliders can also be launched in a relatively short time, day and night, in most weather conditions, either from small or large vessels. They are relatively easy to operate and maintain. These facts lend to their usage for operational applications.

The goal is to illustrate how an observing system utilizing gliders is useful not only for research of oceanographic processes over the long term (months to years), but how such a system can increase the capacity to monitor and forecast the evolution 
Ocean Sci. Discuss., doi:10.5194/os-2016-43, 2016

Manuscript under review for journal Ocean Sci.

Published: 28 June 2016

(c) Author(s) 2016. CC-BY 3.0 License.

of small scale intense ocean features. This paper demonstrates how a single ocean glider measuring temperature and salinity profiles can significantly improve short-term (few days) regional forecasts.

The structure of this paper is as follows. In the next section the circulation patterns of the Levantine basin are described. This is followed by a description of the experimental methodology, including the glider operations and configuration, model

5 system description, experimental setup, and operational chain. In section 3, the results of the combined numericalobservational experiment are presented against the known oceanographic processes of the region, with emphasis on the performance improvements of the operational assimilative forecasting system as compared to the non-assimilative one. The value of glider data at the regional and coastal scale is quantified and discussed in section 4, in relation to other sources of data typically used at the regional and basin scale. Final conclusions are summarized in section 5.

\section{2. The Levantine Basin}

The general circulation of the eastern Mediterranean has been studied since the early 20th century (Nielsen, 1912). This view was revised in recent decades based on observations, numerical simulations, and remotely-sensed data (Hecht et al., 1988; Ozsoy et al., 1989; Robinson et al., 1991; Tziperman and Malanotte-Rizzoli, 1991; Pinardi and Masetti 2000; Alhammoud et al., 2005; Gerin et al., 2009; Amitai et al., 2010; Rosentraub and Brenner, 2007). Summarizing the above studies is beyond

15 the scope of this paper, however, it should be noted that the surface circulation has been shown to be complex and energetic on many scales (Amitai et al, 2010; Menna et al, 2012). The cyclonic Rhodes Gyre between Greece, Cyprus and Turkey in the central Levantine supports Levantine Intermediate Water (LIW) formation, which spreads throughout the basin in anticyclonic eddies, even eastward and southward against the mean flow (Wu and Haines, 1996). Meandering cross-basin flow features of incoming Atlantic Water (AW) have been observed (Robinson et al., 1987, 1991), which reach as far as Egypt

20 and even Cyprus before splitting into branches, and interact with topography and several mesoscale features like the Egypt and Cyprus eddies (Brenner, 1989), the Shikmona Gyre (Ozsoy et al., 1989), and other highly variable eddies.

Despite these efforts, there are still a number of circulation features that are poorly observed or understood, which lend themselves to glider-based experiments, such as mesoscale and submesoscale eddies mentioned above. Most relevant for this study, an anti-cyclonic feature called the Cyprus eddy has often been observed south of Cyprus, with low spatial resolution,

25 for several years in the 1980s (Brenner, 1989) the 1990s (Zodiatis et al. 2005), and in the 2000s (Hayes et al., 2011). It is often the dominant feature of the circulation in the Cyprus basin. It is not yet clear if the LIW core of the Cyprus eddy is formed from local processes as suggested by Brenner et al. (1991) or carried from other regions of subduction. This lack of detailed observations regarding mesoscale structure and the processes governing its evolution drive the continued use of gliders from 2009 to the present in general, and the current study on predictability in particular. Knowing the position and

30 strength of this feature is critical to any marine activity requiring knowledge of the currents, yet since glider missions began in 2009, the apparently permanent feature changes position, strength and structure on a time scale of months (Bosse et al., 2016; Hayes et al., in preparation). This would seem to agree with the conclusion of Amitai et al. (2010) that the Levantine 
Ocean Sci. Discuss., doi:10.5194/os-2016-43, 2016

Manuscript under review for journal Ocean Sci.

Published: 28 June 2016

(c) Author(s) 2016. CC-BY 3.0 License.

basin has turbulent fluctuations on the order of the mean flow, so no mesoscale feature can be considered persistent on the annual timescale (except for the Ierapetra Eddy east of Crete).

\section{Methods}

\subsection{Glider Observations}

5 In this experiment, a glider mission that took place from 2011/12/16 to 2012/06/01 (Figure 1) is used in operational data assimilation. A total of 553 dives in 169 days covering $2651 \mathrm{~km}$ over ground were achieved with one of the University of Cyprus underwater Seagliders. The glider is rated to $1000 \mathrm{~m}$ and normally carries a standard sensor payload. Non-pumped conductivity-temperature-depth sensors (CTD) from SeaBird Electronics are installed (SBE-4 and SBE-5) as well as a SeaBird dissolved oxygen sensor (SBE-43). It was programmed to sample more frequently in the upper water column, and

10 less frequently in the deep ocean in order to conserve batteries. Data were sent to the laboratory over the Iridium satellite communication network after every dive, at which time data were prepared immediately for the data assimilation system. Vertical speed was typically programmed for $7.5 \mathrm{~cm} \mathrm{~s}^{-1}$ and desired pitch was $+/-15.0^{\circ}$. Typical speed and pitch during the dive/climb stayed very close (within $10 \%$ ), with exceptions near waypoints, when gliders dive more steeply in order not to overshoot the waypoint. Dives were programmed to the maximum depth possible $(1000 \mathrm{~m})$ except during initial test dives

15 and where bathymetry prevented it. The latter only occurs very near the coast (about 12-15 nautical miles) and near two major seamounts: the Hecateaus ridge about 30 nautical miles south of Larnaca (minimum depth about 200 m; for mentioned locations see Figure 2), and the Eratosthenes Seamount about 50 miles south of Limassol (minimum depth about $700 \mathrm{~m}$ ). A typical dive to $1000 \mathrm{~m}$ takes about 7 hours and covers horizontal distance of $6 \mathrm{~km}$ (through the water, currents could increase or reduce the distance over ground).

20 Based on the near real time observations, the glider mission was sometimes altered in order to more fully sample the Cyprus eddy, to locate its center or extent, or simply to avoid unfavorable currents. Starting in Limassol, in south-central Cyprus, the butterfly pattern on the eastern side of the domain was completed in two months (with extra transects at the southeast to sample the Cyrus Eddy). The following six weeks, the glider carried out the westernmost butterfly before running into strong head-currents near the southern edge of the domain. It was commanded to skirt north of the Cyprus eddy

25 to the far southeast corner and to continue with a diagonal leg of the butterfly on the east side ending in Limassol. The mission finished with a southward segment south of Limassol followed by a "dogleg" return to Limassol (again in order to avoid strong currents).

Glider temperature and salinity profiles were prepared for data assimilation as follows. Firstly, only upcasts were used, because the higher vertical speeds (up to $0.20 \mathrm{~m} \mathrm{~s}^{-1}$ ) during the initial dive phase caused more spurious salinity values

30 as the glider passed through the thermocline. Also, vertical speed was steadier on the upcast, since the glider adds buoyancy anytime the speed drops below the target speed. A range check was performed: for temperature the range was $10{ }^{\circ} \mathrm{C}$ to $33^{\circ} \mathrm{C}$ and for salinity the range was 35 to 41 . In situ temperature was converted to potential temperature and an offset of $-10{ }^{\circ} \mathrm{C}$ 
Ocean Sci. Discuss., doi:10.5194/os-2016-43, 2016

Manuscript under review for journal Ocean Sci.

Published: 28 June 2016

(c) Author(s) 2016. CC-BY 3.0 License.

was applied in order to be comparable with the model. Salinity was reduced by 35 for the same reason. Finally, temperature and salinity profiles were assumed vertical, and time stamped and assigned latitude and longitude based on the glider GPS fix, typically a few minutes after surfacing. In reality, the upcast was slanted with a horizontal displacement of approximately $3 \mathrm{~km}$ (i.e. transecting approximately three grid points, see following model description) from bottom to top in

5 the typical $1000 \mathrm{~m}$ dive.

\subsection{Ocean Model}

The Oceanography Center at the University of Cyprus has developed an operational flow forecasting system based on the Princeton Ocean Model (POM) known as the Cyprus Coastal Ocean Model (CYCOM). Code can be found at the supplemental information S1.The version of CYCOM discussed here is nested within a regional model of the Eastern

10 Mediterranean (Aegean Levantine Eddy Resolving Model: ALERMO), which is in turn nested within the operational regional model of the Mediterranean (Mediterranean Forecasting System: MFS). Both nesting procedures use one-way, passive downscaling techniques. This version of CYCOM is similar to that of Zodiatis et al. (2008) but with horizontal grid spacing of $1.0 \mathrm{~km}$ and with the open southern and western boundaries at $33.0{ }^{\circ} \mathrm{N}$ and $31.0{ }^{\circ} \mathrm{E}$, respectively. See Figure 2 . The resulting longitude-latitude grid has dimension of 489 x 438 grid points. Vertical sigma levels are 24 and are logarithmic 15 near the top and bottom. Bottom bathymetry is a bilinearly-interpolated version of the 1-minute U.S. Navy Digital Bathymetric Database. Minimum depth is set to $5 \mathrm{~m}$ and maximum is $2770 \mathrm{~m}$. The bathymetry was smoothed to avoid numerical artifacts. Internal and external time steps were 120 and 2 seconds, respectively. For more model details, please see Zodiatis et al. (2008). The present CYCOM also uses atmospheric forcing from the Skiron forecasting system of the University of Athens (Kallos, 1997, http://forecast.uoa.gr/). Skiron provides hourly fields for 120 hours updated on a daily

20 basis and $5 \mathrm{~km}$ resolution.

The Aegean Levantine Eddy Resolving Model (ALERMO) of the University of Athens was used in this study to initialize CYCOM (http://pelagos.oc.phys.uoa.gr/mfstep/bulletin/). It has a horizontal resolution of $1 / 30^{\circ}$, and does not include data assimilation of in situ data, only Sea Level Anomaly. It is in turn nested within the Mediterranean Forecasting System (MFS) v2, with daily restart and also uses Skiron. It has one open boundary on the west at $20^{\circ} \mathrm{E}$. An initialization routine was used

25 in order to reduce numerical oscillations and incorrect transports across density surfaces over steep topography: the horizontally-average density profile is computed and subtracted from the density variable before solving the density equation. The basin MFS model is described by Tonani et al. (2008) and Pinardi et al. (2003). During the experiments discussed here, data on SLA, ARGO, and XBT were assimilated using the 3DVAR OceanVar package (Dobricic and Pinardi, 2008).

\section{3.3 Data Assimilation Technique}

For this study, OceanVar (Dobricic and Pinardi, 2008) has been adapted for use in CYCOM. OceanVar iteratively finds the minimum of the cost function of the analyzed state vector written as the sum of the background error and observation error. 
Ocean Sci. Discuss., doi:10.5194/os-2016-43, 2016

Manuscript under review for journal Ocean Sci.

Published: 28 June 2016

(c) Author(s) 2016. CC-BY 3.0 License.

The method of minimization of the cost function is described in detail in Dobricic and Pinardi(2008) and used in similar studies in the Mediterranean by Dobricicet al. (2010), and Adani et al. (2011).

This technique requires the computation of the vertical empirical orthogonal functions (EOFs) of the temperature and salinity anomalies from the monthly mean profiles at each model point. Historical CYCOM operational forecast runs were used (24

5 months of daily average output). From the first five of these EOFs for the month of interest, a set of measured misfit profiles of temperature and salinity can be converted to model innovations, which are 3-D corrections to the model fields, applied at the next model start in forecast mode. OceanVar was configured with a radius of correlation of $10 \mathrm{~km}$. An analysis window of 24 hours was chosen, centered on 1200h. Observational errors were assigned constant values of 0.15 Co and 0.05 for temperature and salinity, respectively. Code can be found at the supplemental information S1.

\section{3.4 Experimental Design}

Glider data were assimilated in the CYCOM only, without influencing the coarser resolution models that provide the initial and boundary conditions, see Figure 3. Every day, the model was run in hindcast mode for 1.5 days, starting 2 days back, during which misfits were computed based on available glider data. At the end of the hindcast, the data assimilation tool OceanVar calculated corrections to the temperature and salinity fields, which were introduced into the initial 20 time steps of

15 a second 1.5 day hindcast run starting one day back. This run also calculated misfits between observations with model (profiles nearest in time and space) and OceanVar again calculated corrections to apply to the forecast of the current day. The forecast run continued for 4.5 days. The daily runs were carried out from 1 December 2011 until 1 June 2012, during which time a single ocean glider carried out the modified butterfly pattern described above, covering a large portion of the domain from 11 December 2011 until 1 June 2012. Note that the latest available open boundary conditions from ALERMO

20 and surface forcing from Skiron were used every day.

A control run was run using the same code at the same time, with exactly the same initial and boundary conditions, but with no temperature or salinity observations assimilated. Both runs produced daily averaged output, daily instantaneous output, and 6-hourly averaged output.

\section{Results}

25 Below is a discussion of the hydrographic structure observed with the glider, and specifically the existence of the Cyprus eddy. This is followed by a demonstration of how assimilation of the glider data improves the model forecast in the vicinity of the eddy. The effect on the dispersion of passive tracer is shown in subsection 4.3.

\subsection{Hydrographic structure and eddy detection}

The existence of the Cyprus eddy with a subsurface core at approximately $360 \mathrm{~m}$ depth is shown in Figure 4 in both the 30 salinity (upper panel) and temperature (lower panel). There is little evidence of the existence of this eddy in sea level. The 
Ocean Sci. Discuss., doi:10.5194/os-2016-43, 2016

Manuscript under review for journal Ocean Sci.

Published: 28 June 2016

(c) Author(s) 2016. CC-BY 3.0 License.

skies were cloudy most of the month of January 2012 so no conclusive SST images exist. The only useful image found was from 11 December 2011 (Figure 5). Practically, without subsurface observations, either by gliders, floats or from ships, it would have been almost impossible to identify this eddy. Data from XBT sections and ARGO floats do exist for this period, but these profiles do not encounter the eddy.

5 Vertical sections from the glider clearly show the water masses and the vertical structure of the Cyprus eddy. The near surface consists of water in the mixed layer, originating from the Atlantic, and modified by surface fluxes. In some places below the mixed layer is a remnant of Atlantic Water (AW). Below that, from about 100-400 m, is found the Levantine Intermediate Water (LIW) which may be formed in the Rhodes Gyre or in other locations in the Eastern Mediterranean as described in Sec. 2. At the position of the Cyprus eddy, a core of LIW is found, with higher temperature and salinity values

10 than surrounding water at the same depth. (Figure 4). The eddy has been observed in the region in detail every year since glider missions began in 2009 , but with position varying by up to $50 \mathrm{~km}$ from a central location of about $34^{\circ} \mathrm{N}, 33^{\circ} \mathrm{E}$ (Bosse et al., 2016; Hayes et al., 2014). Diameter at the depth of the core is normally about $80 \mathrm{~km}$. Below the eddy, there is a slow transition from LIW to Eastern Mediterranean Deep Water (EMDW) towards the bottom. The observed temperature and salinity also show the anti-cyclonic circulation (also detected from glider drift calculations), since the circulation is

15 approximately in geostrophic balance.

\subsection{Model comparison}

Assimilating temperature and salinity profiles produces large differences in the vicinity of Cyprus eddy between the control run and the data assimilative (d/a) run. The largest temperature and salinity differences are found at depths between 250 and $500 \mathrm{~m}$, and the resulting misfits contain sharp vertical gradients (Figure 6, online supplement S2). The observations differ

20 greatly from the runs at day 50, because the glider encountered the core of the eddy, with large differences in temperature and salinity. It is clear from this figure that the vertical resolution of the model is less than that of the observation. The most striking effect is seen at maps of corrections produced by OceanVar using the above misfits and resulting model differences the following day at $360 \mathrm{~m}$ (Figure 7). When the glider is outside the eddy, say day 175, salinity differences at $360 \mathrm{~m}$ are smaller. They are still visible throughout the domain, and are larger near the eddy region. Animations of the salinity

25 corrections and salinity field differences for the entire experiment duration can be found in the online supplement (S3 and S4, respectively).

Most relevant are the differences in ocean currents between the two runs (Figure 8). In the Cyprus eddy area, after 50 days, the $\mathrm{d} / \mathrm{a}$ run currents at $1 \mathrm{~m}$ show a small anticyclone which is absent in the control run. Currents at depth are also quite different in this region, e.g. at $360 \mathrm{~m}$ depth (not shown). The effects of these differences in circulation on pollution 30 dispersion will be demonstrated in the next subsection.

In Figure 9 the values of sea surface height of the d/a run and the difference from the control run are shown at day 50 (24 January 2012) of the simulation. As expected, the difference is visible mainly in the vicinity of the eddy, in the rest of the domain the differences are very small. Being identical at the start, small differences between the runs begin to appear. In the 
Ocean Sci. Discuss., doi:10.5194/os-2016-43, 2016

Manuscript under review for journal Ocean Sci.

Published: 28 June 2016

(c) Author(s) 2016. CC-BY 3.0 License.

vicinity of the eddy, $d / a$ run sea level shows higher values by approximately $0.04 \mathrm{~m}$ when the glider passes though the eddy. An example of a period in which the glider was far from the core, say day 174 (28 May 2012), is shown in the lower panel of Figure 9. Differences are much smaller, although they do exist. Differences indicate a different spatial pattern of mesoscale and submesoscale features in the interior regions, with the coastally-linked sea surface elevation in agreement between the

5 runs. Away from the eddy and from the glider, XBT temperature profiles from 23 February 2012 around the basin (stations on map of Figure 11) show comparable agreement with both control and d/a runs (profiles not shown here).

The results so far were analyzed mainly qualitatively. To provide a quantitative estimate, the glider observations of the forecasted day are treated as independent observations, as these have not been assimilated yet into the model, following Dobricic et al (2010) and Adani et al. (2011). The RMS differences between the model forecasted temperature and salinity

10 fields and those measured by the glider (black lines in Figure 6) are calculated for each profile for the entirety of each run, both control and d/a. This is done for the entire water column, although as can be seen from Figure 6, most of the variability was in the upper $500 \mathrm{~m}$. The results are summarized in Table 1.

\subsection{Pollution dispersion}

To evaluate the potential effect of assimilating glider data on the dispersion of pollutants, we use the velocity fields from the

15 control and the d/a models and computed the Lagrangian trajectories of particles driven by the model currents using the MatLab toolbox 'PaTATO' (Fredj et al., 2016). We seeded particles at inside the blue rectangle shown in Figure 10, and track them from 21 January, 2012, 6:00 until 28 January, 2012, at 18:00. Their end points are shown by the red circles and the grey and black regions their visited places. We used snapshots of the velocity fields from every 6 hours and used linear interpolation in between. Full animations can be found in the Supplementary material (S5 and S6). We assume the particles

20 are passive and have no inertia, and that they do interact with each other.

The difference between the end points when using the control and the model with assimilated glider data is pretty large. Clearly, in case of an oil spill, if one has to know where the pollution is expected to go, there is a clear advantage in using the model with assimilation.

\section{Discussion}

25 Comparisons with a control run showed that the model analysis better captures the presence of an anticyclonic eddy when assimilating glider T-S profiles. In particular, intermediate water of high temperature and salinity was detected by the glider, and since no such water mass existed in the model ocean, it was 'inserted' into the $\mathrm{d} / \mathrm{a}$ model. The resulting change in the density field caused a change in the circulation field which was realistic and compares favorably with the currents observed from the glider drift. Remote sensing of sea surface temperature and chlorophyll-a do not provide reliable information on the

30 circulation features simulated here, especially in the case of the Cyprus eddy which has been shown above to be primarily a subsurface feature. Nevertheless, there is a suggestion that surface temperature was slightly warmer in the region of the eddy 
Ocean Sci. Discuss., doi:10.5194/os-2016-43, 2016

Manuscript under review for journal Ocean Sci.

Published: 28 June 2016

(c) Author(s) 2016. CC-BY 3.0 License.

in December and January, possibly through vertical mixing of the intermediate water to the surface. This is visible both in the single clear SST image and the d/a SST image (Figure 5 and Figure 8, respectively)

Sea surface altimetry is a more likely candidate to detect a subsurface feature, even though in this case the eddy is not easily detected because of its small geographical size. By looking at differences between the control and d/a runs, it is

5 possible to identify the insertion of the eddy (Figure 9), as well as small but significant differences at the mesoscale throughout the interior. There is no convincing evidence that shows which of the control or the $\mathrm{d} / \mathrm{a}$ mesoscale structure is closer to reality, but this could be investigated further by a careful analysis of the MADT and other SST products. A preliminary look at SST-derived singularity exponents of Turiel (2009) for December 2011 shows a highly complex and variable set of coherent structures (Turiel, pers. comm.) that could be used as a reference. Finally, a comparison with

10 concurrent XBT data show that the analysis was no worse than the control run in simulating temperature profiles far from the glider track Profiling float (ARGO) data were not present near the eddy.

For practical applications, it is important to provide quantitative comparisons of predictions of the d/a model with independent observations. To do this, glider-measured values of temperature and salinity are compared with values predicted at that location. That prediction did of course assimilate temperature and salinity from the same glider, but at that point in

15 time the glider was approximately 10-20 km away from the measurements used for the comparison. The internal Rossby radius for this region is between 10 and $12 \mathrm{~km}$ (Amitai et al., 2010). The RMS values in Table 1 clearly indicate the improvement of the model fields in the vicinity of the glider. Not evident from such a table is the persistence of these corrections: on 5 February 2012, after about two weeks away from the eddy, the glider returned and again introduced corrections because the eddy had dissipated to a large degree (online supplement S3 of salinity corrections at $360 \mathrm{~m} \mathrm{~S}$ ).

20 Obviously, model physics and/or forcing contain errors. In this case, since the eddy is near the open boundary, it is likely that the nesting model (ALERMO) was not providing consistent boundary conditions and contributed to the breakdown of the eddy.

\section{Conclusions}

The specific experiment illustrates the value of glider data when introduced in high-resolution models and provides

25 suggestions for the most effective way to improve forecast skill. While other elements of the ocean observing system failed to adequately characterize a mesoscale eddy, a single glider was able to improve the ocean state estimate. It is evident that assimilating in situ observations disturbs the resulting analysis, and in the vicinity of the assimilation in the direction of reality. The simple comparison with the entire set of glider observations before assimilation show that the analysis is better than the control run in the vicinity of the glider as it scans the domain. Far from the vicinity, changes also develop indirectly,

30 as anomalies propagate around the domain.

While the predictive skill is seen to increase in the vicinity of the assimilation, depending on the source model error, the improvement can disappear very soon after the observations cease. In this study, a core of intermediate water is rapidly 
Ocean Sci. Discuss., doi:10.5194/os-2016-43, 2016

Manuscript under review for journal Ocean Sci.

Published: 28 June 2016

(c) Author(s) 2016. CC-BY 3.0 License.

dispersed by interaction with the open boundary currents only a few weeks after it is 'inserted.' In the future, it would be valuable to continue the two simulations until they converged, in order to determine the time scale of the model error growth. It would be even more useful for end-user applications to expand the model domain so that data assimilation is not carried out near open boundaries. This should allow the internal dynamics generated by the $\mathrm{d} / \mathrm{a}$ system to persist according to model

5 physics rather than forcing errors.

From a practical perspective, a number of improvements are planned. Firstly, the open boundary on the southern edge will be removed, and the domain extended to the African coast for the reasons mentioned above. Secondly, the vertical resolution of the model will be increased, since in deep water, only a few grid points span the core of the Cyprus eddy. Finally, the vertical EOF used in OceanVar are planned be updated based on a re-analysis including all glider missions over the last five

10 years. In this way, the predictive ability of the system should be greatly improved.

Team List - Unknown.

Copyright Statement - None at present.

15 Code Availability-Supplemental Information S1

Data Availability - Glider data are available at https://doi.pangaea.de/10.1594/PANGAEA.859003

Appendices - None.

Supplement Links - Provided by Copernicus.

20 Author Contribution - Dr. Hayes set up and carried out the glider missions and model runs and wrote the majority of the manuscript. Dr.Dobricic provided the OceanVar code and supported the implementation and configuration for CYCOM. Dr.Gildor contributed to the figure and manuscript preparation and carried out the tracer runs based on the model output.

Acknowledgements - This work spans a number of projects, each of which contributed part of the necessary funding to 25 complete the study: European Union 6th Framework Programme (FP6), under grant agreement 036355 ECOOP: European Coastal-shelf sea Operational observing and forecasting system, European Union 7th Framework Programme (FP7 20072013), under grant agreement number 284321 GROOM: Gliders for Research Ocean Observation and Management, Cyprus RPF and EUstrategic funds under grant agreement EPYAN/0506/10 YPOKINOYMODA: Autonomous underwater vehicles (AUV) for oceanographic measurements. Also, this project has received funding from the European Union's Horizon 2020

30 research and innovation programme under grant agreement No 635359: BRIDGES: Bringing Together Research and Industry for the Development of Glider Environmental Services.

Disclaimer-Data and code are provided "as-is." 
Ocean Sci. Discuss., doi:10.5194/os-2016-43, 2016

Manuscript under review for journal Ocean Sci.

Published: 28 June 2016

(c) Author(s) 2016. CC-BY 3.0 License.

\section{References}

Adani, M., Dobricic, S., Pinardi, N.: Quality Assessment of a 1985-2007 Mediterranean Sea Reanalysis. Journal of Atmospheric and Oceanic Technology 28, 569-589. doi:10.1175/2010JTECHO798.1, 2011.

Alhammoud, B., Béranger, K., Mortier, L., Crépon, M., Dekeyser, I.: Surface circulation of the Levantine Basin:

5 Comparison of model results with observations. Progress in Oceanography 66, 299-320. doi:http://dx.doi.org/10.1016/j.pocean.2004.07.015, 2005.

Amitai, Y., Lehahn, Y., Lazar, A., Heifetz, E.: Surface circulation of the eastern Mediterranean Levantine basin: Insights from analyzing 14 years of satellite altimetry data. Journal of Geophysical Research: Oceans 115.doi:10.1029/2010JC006147, 2010.

10 Bosse, A., Testor, P., Hayes, D.R., Ruiz, S., Mauri, E., Charantonis, A., D’Ortenzio, F., Mortier, L.: Hydrographical and dynamical reconstruction of the Warm Core Cyprus Eddy from gliders data. Presented at the EGU General Assembly 2016, Vienna, 2016.

Brenner, S.: Structure and evolution of warm core eddies in the eastern Mediterranean Levantine Basin. Journal of Geophysical Research: Oceans 94, 12593-12602. doi:10.1029/JC094iC09p12593, 1989.

15 Dobricic, S., Pinardi, N., Adani, M., Tonani, M., Fratianni, C., Bonazzi, A., Fernandez, V.: Daily oceanographic analyses by Mediterranean Forecasting System at the basin scale. Ocean Science 3, 149-157, 2007.

Dobricic, S., Pinardi, N., Testor, P., Send, U.: Impact of data assimilation of glider observations in the Ionian Sea (Eastern Mediterranean). Dynam. Atmos. Ocean 50, 78-92. doi:10.1016/j.dynatmoce.2010.01.001, 2010.

Dobricic, S., Dufau, C., Oddo, P., Pinardi, N., Pujol, I., Rio, M.-H.: Assimilation of SLA along track observations in the

20 Mediterranean with an oceanographic model forced by atmospheric pressure. Ocean Science Discussions 9, 1577-1598. doi:10.5194/osd-9-1577-2012, 2012.

Dobricic, S., Pinardi, N.: An oceanographic three-dimensional variational data assimilation scheme. Ocean Modelling 22, 89-105.doi:http://dx.doi.org/10.1016/j.ocemod.2008.01.004, 2008.

Dobricic, S., Pinardi, N., Testor, P., Send, U.: Impact of data assimilation of glider observations in the Ionian Sea (Eastern

25 Mediterranean). Dynam. Atmos. Ocean 50, 78-92. doi:10.1016/j.dynatmoce.2010.01.001, 2010.

Edwards, C.A., Moore, A.M., Hoteit, I., Cornuelle, B.D.: Regional Ocean Data Assimilation. Annual Review of Marine Science 7, 21-42. doi:10.1146/annurev-marine-010814-015821, 2015.

Gerin, R., Poulain, P.-M., Taupier-Letage, I., Millot, C., Ben Ismail, S., Sammari, C.: Surface circulation in the Eastern Mediterranean using drifters (2005-2007). Ocean Science 5, 559-574. doi:10.5194/os-5-559-2009, 2009.

30 Fredj, E., D.F. Carlson, Y. Amitai, A. Gozolchiani, and H. Gildor, The particle tracking and analysis toolbox (PaTATO) for Matlab, Limnol. Oceanogr.: Methods, doi: 10.1002/lom3.10114, 2016.

Hayes, D.R.: Physical oceanography from Seaglider mission CNCY201114910. Oceanography Center, University of Cyprus, Nicosia, doi:10.1594/PANGAEA.859003, 2016. 
Ocean Sci. Discuss., doi:10.5194/os-2016-43, 2016

Manuscript under review for journal Ocean Sci.

Published: 28 June 2016

(c) Author(s) 2016. CC-BY 3.0 License.

Hayes, D.R., Zodiatis, G., Konnaris, G., Hannides, A., Solovyov, D., Testor, P.: Glider transects in the Levantine Sea: Characteristics of the warm core Cyprus eddy, in: OCEANS 2011 IEEE - Spain. pp. 1-9. doi:10.1109/OceansSpain.2011.6003393, 2011.

Hayes, D.R., Hannides, A., Zodiatis, G., Georgiou, G., Gildor, H., Testor, P.: Description of the Long-lived Subsurface

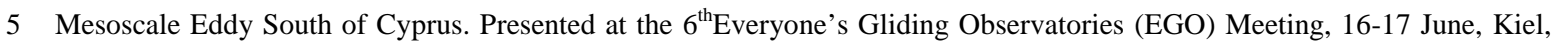
2014.

Hecht, A., Pinardi, N., and Robinson, A.: Currents, water masses, eddies and jets in the Mediterranean Levantine basin, J. Phys. Oceanogr.,18, 1320-1353, 1988.

Hecht, A., Pinardi, N., Robinson, A.R.: Currents, Water Masses, Eddies and Jets in the Mediterranean Levantine Basin.

10 Journal of Physical Oceanography 18, 1320-1353. doi:10.1175/1520-0485(1988)018<1320:CWMEAJ>2.0.CO;2, 1988.

Kallos, G., Nickovic, S., Papadopoulos, A., Jovic, D., Kakaliagou, O., Misirlis, N., Boukas, L., Mimikou, N., Sakellaridis, G.,Papageorgiou, J.: The regional weather forecasting system SKIRON: An overview, in: Proceedings of the Symposium on Regional Weather Prediction on Parallel Computer Environments. p. 17, 1997.

Li, Z., McWilliams, J.C., Ide, K., Farrara, J.D.: Coastal ocean data assimilation using a multi-scale three-dimensional

15 variational scheme. Ocean Dynamics 65, 1001-1015. doi:10.1007/s10236-015-0850-x, 2015.

Liblik, T., Karstensen, J., Testor, P., Alenius, P., Hayes, D.R., Ruiz, S., Heywood, K.J., Pouliquen, S., Mortier, L., Mauri, E.: Potential for an underwater glider component as part of the Global Ocean Observing System. Methods in Oceanography. doi:10.1016/j.mio.2016.05.001, 2016. (accepted)

Malanotte-Rizzoli, P., Tziperman, E.: The Oceanographic Data Assimilation Problem: Overview, Motivation and Purposes,

20 in: Malanotte-Rizzoli, P. (Ed.), Modern Approaches to Data Assimilation in Ocean Modeling, Elsevier Oceanography Series. Elsevier, pp. 3-17, 1996.

Menna, M., Poulain, P.-M.,Zodiatis, G., Gertman, I.: On the surface circulation of the Levantine sub-basin derived from Lagrangian drifters and satellite altimetry data. Deep Sea Research Part I: Oceanographic Research Papers 65, 46-58. doi:10.1016/j.dsr.2012.02.008, 2012.

25 Nielsen, J.N.: Hydrography of the Mediterranean and adjacent waters, Tech. Rep. 1 in: Report of the Danish Oceanographic Expedition 1908-1910 to the Mediterranean and Adjacent Waters. Copenhagen, pp. 72-191, 1912.

Nilsson, J.A., Dobricic, S., Pinardi, N., Taillandier, V., Poulain, P.-M.: On the assessment of Argo float trajectory assimilation in the Mediterranean Forecasting System. Ocean Dynamics 61, 1475-1490, 2011.

Özsoy, E., Hecht, A., Ünlüata, Ü.: Circulation and hydrography of the Levantine Basin. Results of POEM coordinated

30 experiments 1985-1986. Progress in Oceanography 22, 125-170. doi:http://dx.doi.org/10.1016/0079-6611(89)90004-9, 1989.

Pinardi, N., Masetti, E., 2000. Variability of the large scale general circulation of the Mediterranean Sea from observations and modelling: a review. Palaeogeography, Palaeoclimatology, Palaeoecology 158, 153-173. doi:http://dx.doi.org/10.1016/S0031-0182(00)00048-1 
Ocean Sci. Discuss., doi:10.5194/os-2016-43, 2016

Manuscript under review for journal Ocean Sci.

Published: 28 June 2016

(c) Author(s) 2016. CC-BY 3.0 License.

Pinardi, N., Allen, I., Demirov, E., De Mey, P., Korres, G., Lascaratos, A., Le Traon, P.-Y., Maillard, C.,Manzella, G., Tziavos, C.: The Mediterranean ocean forecasting system: first phase of implementation (1998-2001). AnnalesGeophysicae 21, 3-20. doi:10.5194/angeo-21-3-2003, 2003.

Robinson, A.R., Hecht, A., Pinardi, N., Bishop, J., Leslie, W.G., Rosentroub, Z., Mariano, A.J., Brenner, S.: Small

5 synoptic/mesoscale eddies and energetic variability of the eastern Levantine basin. Nature 327, 131-134. doi:10.1038/327131a0, 1987.

Robinson, A.R., Golnaraghi, M., Leslie, W.G., Artegiani, A., Hecht, A., Lazzoni, E., Michelato, A., Sansone, E., Theocharis, A., Ünlüata,Ü.: The Mediterranean Sea The eastern Mediterranean general circulation: features, structure and variability. Dynamics of Atmospheres and Oceans 15, 215-240. doi:http://dx.doi.org/10.1016/0377-0265(91)90021-7, 1991.

10 Rosentraub, Z., Brenner, S.: Circulation over the southeastern continental shelf and slope of the Mediterranean Sea: Direct current measurements, winds, and numerical model simulations. Journal of Geophysical Research 112.doi:10.1029/2006JC003775, 2007.

Rudnick, D.L.: Ocean Research Enabled by Underwater Gliders. Annual Review of Marine Science 8, 519-541. doi:10.1146/annurev-marine-122414-033913, 2016.

15 Shulman, I., Rowley, C., Anderson, S., DeRada, S., Kindle, J., Martin, P., Doyle, J., Cummings, J., Ramp, S., Chavez, F., Fratantoni, D., Davis, R.: Impact of glider data assimilation on the Monterey Bay model. Deep-Sea Res. II 56, $188-198$. doi:10.1016/j.dsr2.2008.08.003, 2009.

Taillandier, V., Dobricic, S., Testor, P., Pinardi, N., Griffa, A., Mortier, L., Gasparini, G.P.: Integration of Argo trajectories in the Mediterranean Forecasting System and impact on the regional analysis of the western Mediterranean circulation.

20 Journal of Geophysical Research 115, C03007, 2010.

Tonani, M., Pinardi, N., Dobricic, S., Pujol, I., Fratianni, C.: A high-resolution free-surface model of the Mediterranean Sea. Ocean Science 4, 1-14., 2008.

Turiel, A., Nieves, V., Garcia-Ladona, E., Font, J., Rio, M.-H., Larnicol, G.: The multifractal structure of satellite sea surface temperature maps can be used to obtain global maps of streamlines. Ocean Science 5, 447-460. doi:10.5194/os-5-447-2009, 252009.

Tziperman, E., Malanotte-Rizzoli, P.: The climatological seasonal circulation of the Mediterranean Sea. Journal of Marine Research 49, 411-434. doi:doi:10.1357/002224091784995783, 1991.

Waters, J., Lea, D.J., Martin, M.J., Mirouze, I., Weaver, A., While, J.: Implementing a variational data assimilation system in an operational 1/4 degree global ocean model. Quarterly Journal of the Royal Meteorological Society 141, 333-349. 30 doi:10.1002/qj.2388, 2015.

Wu, P., Haines, K.:Modeling the dispersal of Levantine Intermediate Water and its role in Mediterranean deep water formation. J. Geophys. Res. 101, 6591-6607.doi:10.1029/95JC03555, 1996.

Zodiatis, G., Drakopoulos, P., Brenner, S., Groom, S.: Variability of the Cyprus warm core Eddy during the CYCLOPS project. Deep Sea Research Part II: Topical Studies in Oceanography 52, 2897-2910. doi:10.1016/j.dsr2.2005.08.020, 2005. 
Ocean Sci. Discuss., doi:10.5194/os-2016-43, 2016

Manuscript under review for journal Ocean Sci.

Published: 28 June 2016

(c) Author(s) 2016. CC-BY 3.0 License.

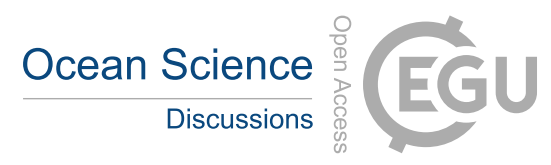

(c) (i)

Zodiatis, G., Lardner, R., Hayes, D.R., Georgiou, G., Sofianos, S., Skliris, N., Lascaratos, A.: Operational ocean forecasting in the Eastern Mediterranean: implementation and evaluation. Ocean Science 4, 31-47. doi:10.5194/os-4-31-2008, 2008. 
Ocean Sci. Discuss., doi:10.5194/os-2016-43, 2016

Manuscript under review for journal Ocean Sci.

Published: 28 June 2016

(c) Author(s) 2016. CC-BY 3.0 License.

\section{Captions}

Figure 1.Track of glider mission 20111216_149_011 from 16 December 2011 to 1 June 2012. Color of the dot indicates temperature at 250 dbar observed on the upcast by Seaglider149. A few key dates are indicated, as well has the Eratosthenes Seamount and Cyprus eddy core. The shaded box indicates the region used for a vertical section in Fig. 4.

5 Figure 2.Domain and bathymetry of the CYCOM model and ALERMO model (inset).

Figure 3. Operational forecast scheme for data assimilation, including hindcasts and forecasts. $\mathrm{T}_{\mathrm{o}}$ is $1200 \mathrm{~h}$ GMT on the day of the operational run. Note that innovations are integrated linearly over the first 20 time steps of the following run.

Figure 4. Vertical section of temperature (top) and salinity (bottom) in January 2012 through the Cyprus eddy region. Horizontal axis is in kilometers from the western edge of the box in Figure 1.

10 Figure 5. Remotely-sensed instantaneous sea surface temperature: on 11 December 2011.

Figure 6. Profiles of model (blue) and glider (red) temperature(left) and salinity (right) for day 49 (23 January 2012) (top), used to calculate the respective misfits (black) and corrections (green) on day 50 (bottom). Note that the corrections are 3-D fields, and only the profile through the glider location is shown here.

Figure 7. Corrections to salinity and glider profile locations (symbol x) for day 49 (23 January 2012) and day 174 (27 May

15 2012) at depth $360 \mathrm{~m}$ only. Difference in salinity at $360 \mathrm{~m}$ between the data assimilative run and control run for day 50 (left) and day 175 (right). The difference is identically zero at day 0.

Figure 8.Current direction and Temperature at $1 \mathrm{~m}$ for day 50 (24 January 2012) for control run (top) and data assimilative run (bottom). Region of Cyprus eddy is $33.5^{\circ} \mathrm{N}, 33.5^{\circ} \mathrm{E}$.

Figure 9. Sea level from CYCOM control run (left) and data assimilative run (right) for 24 January 2012 (day 50, top), and

2028 May 2012 (day 175, bottom). Day 0 was 6 December 2011.The same scales are used for both periods.

Figure 10. Lagrangian trajectories of particles driven by the model currents for control (left) and d/a (right) runs from 21 January, 2012, 6:00 until 28 January, 2012, at 18:00.

Figure 11. Data assimilated by the MFS system during the study: XBT (crosses, left) and ARGO float (circles, left), and SLA tracks (right). ALERMO surface currents and temperature for 24 January 2012 (bottom) using the same scales as in 25 Fig. 8.

\section{Supplemental Information}

S1 Codes for CYCOM and OceanVar.

S2 Animations of daily temperature and salinity misfit (black) and correction (green) vertical profiles at glider locations.

S3 Animations of daily salinity corrections at $360 \mathrm{~m}$ depth applied during the d/a run.

30 S4 Animations of daily salinity difference fields at $360 \mathrm{~m}$ depth between the $\mathrm{d} / \mathrm{a}$ run and the control run.

S5 Lagrangian trajectories of particles driven by the control run currents from 06:00 21 January, 2012 until 18:00 28 January, 2012. 
Ocean Sci. Discuss., doi:10.5194/os-2016-43, 2016

Manuscript under review for journal Ocean Sci.

Published: 28 June 2016

(c) Author(s) 2016. CC-BY 3.0 License.

(c) (i)

S6 Lagrangian trajectories of particles driven by the d/a model currents from 6:00 21 January, 2012 to 18:00 on 28 January, 2012.

Figures

5

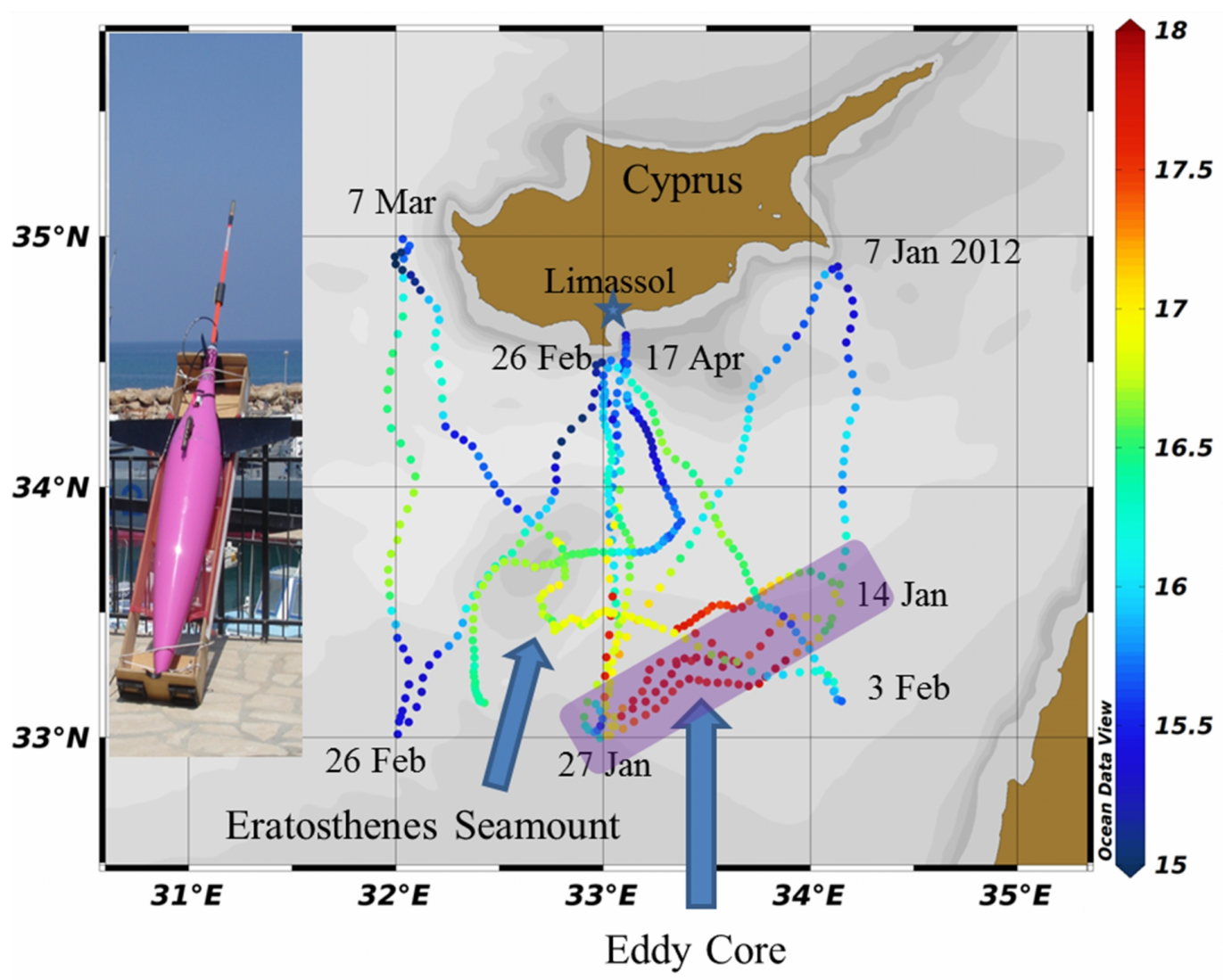

Figure 2.Track of glider mission 20111216_149_011 from 16 December 2011 to 1 June 2012. Color of the dot indicates temperature at 250 dbar observed on the upcast by Seaglider149. A few key dates are indicated, as well has the Eratosthenes Seamount and Cyprus eddy core. The shaded box indicates the region used for a vertical section in Fig. 4. 
Ocean Sci. Discuss., doi:10.5194/os-2016-43, 2016

Manuscript under review for journal Ocean Sci.

Published: 28 June 2016

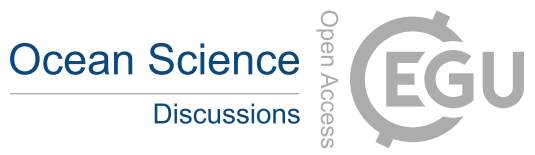

(c) Author(s) 2016. CC-BY 3.0 License.

(c) (1)

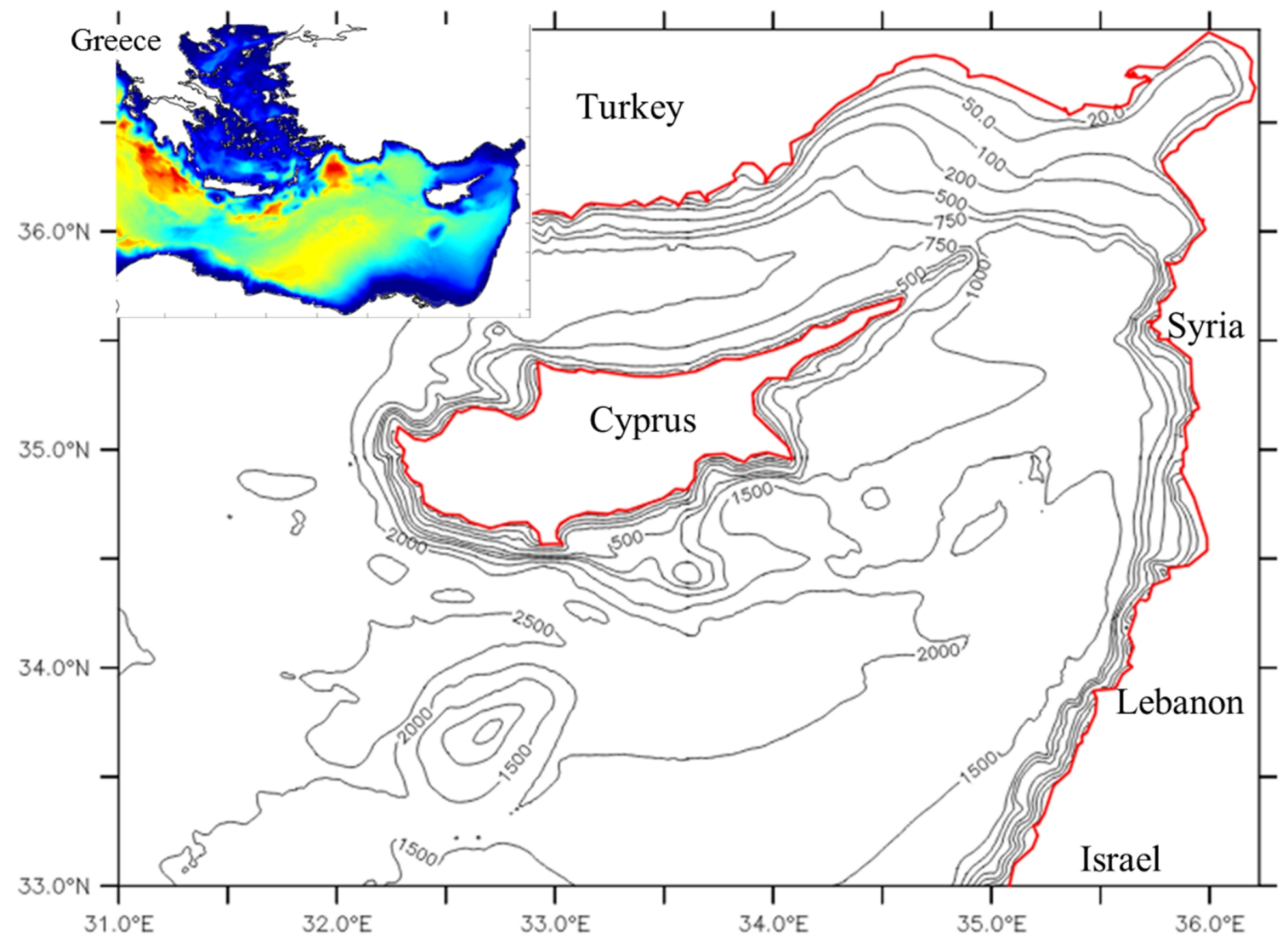

Figure 2. Domain and bathymetry of the CYCOM model and ALERMO model (inset). 
Ocean Sci. Discuss., doi:10.5194/os-2016-43, 2016

Manuscript under review for journal Ocean Sci.

Published: 28 June 2016

(c) Author(s) 2016. CC-BY 3.0 License.

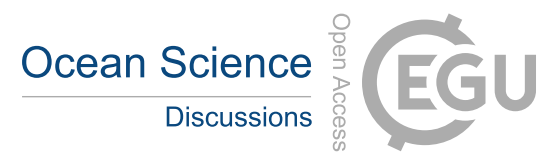

(c) (i)

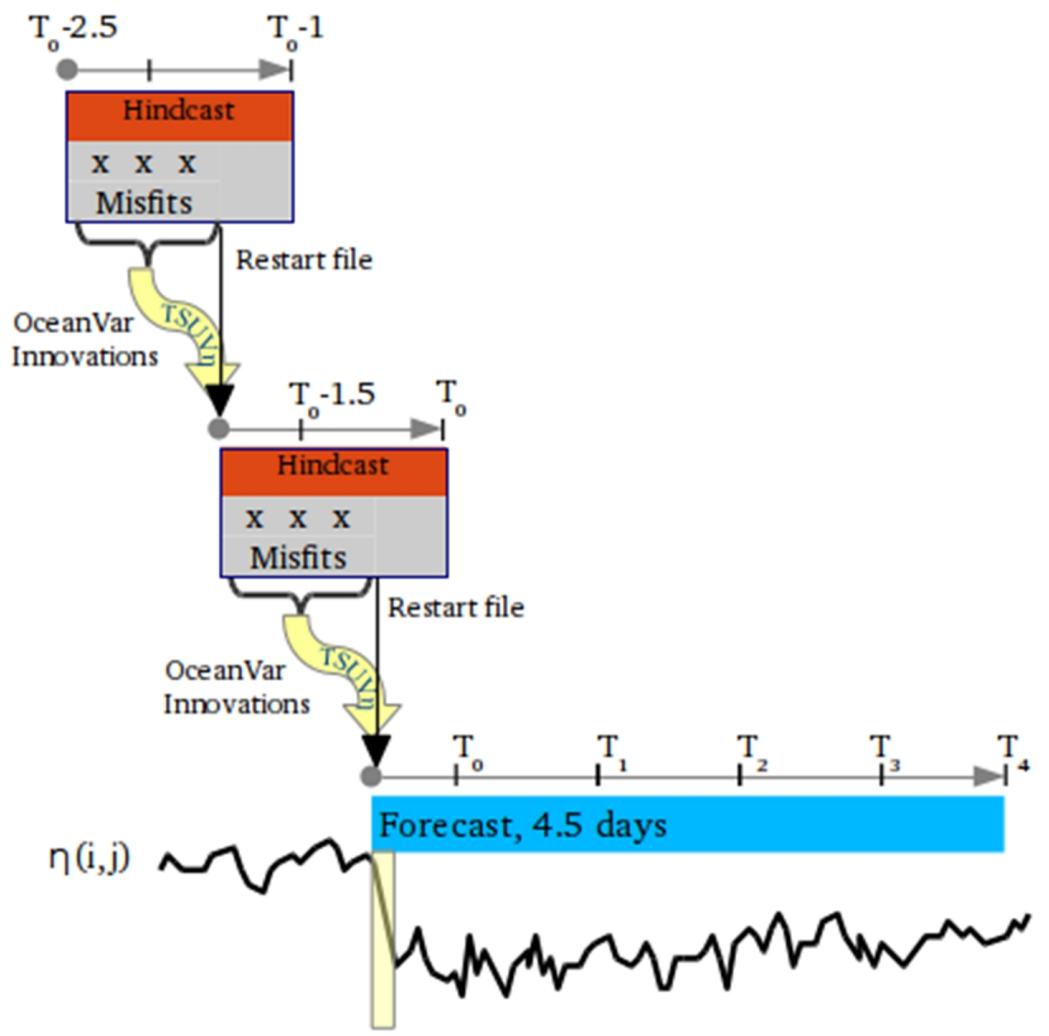

Figure 3. Operational forecast scheme for data assimilation, including hindcasts and forecasts. To is 1200h GMT on the day of the operational run. Note that innovations are integrated linearly over the first 20 time steps of the following run. 
Ocean Sci. Discuss., doi:10.5194/os-2016-43, 2016

Manuscript under review for journal Ocean Sci.

Published: 28 June 2016

(c) Author(s) 2016. CC-BY 3.0 License.
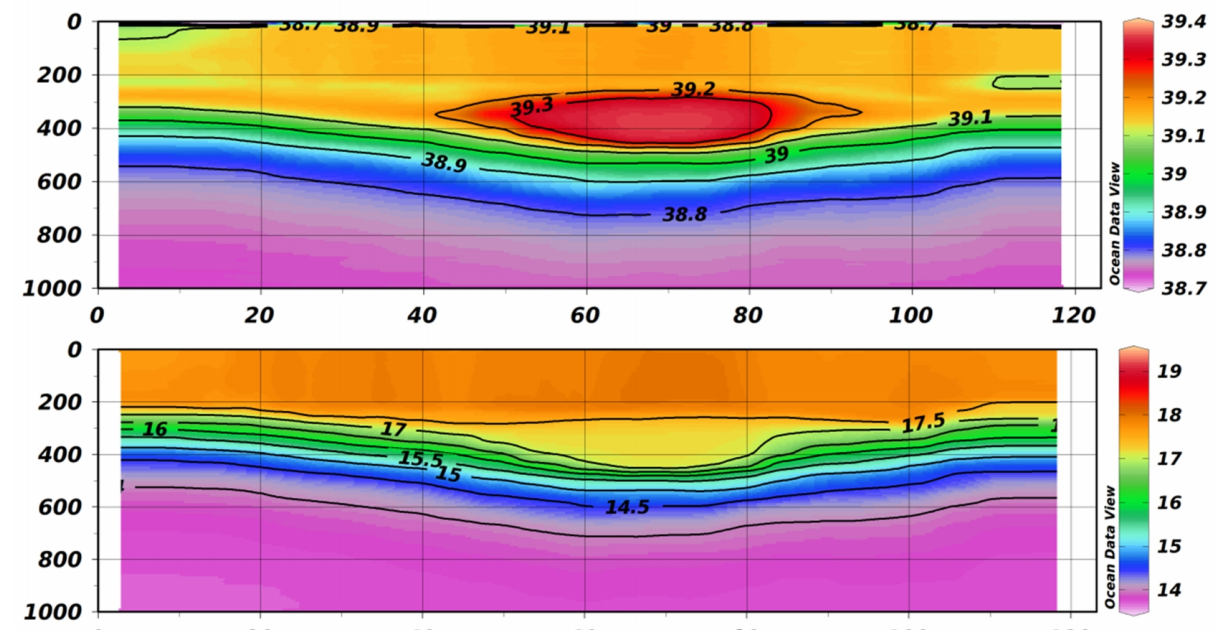

Figure 4. Vertical section of temperature (top) and salinity (bottom) in January 2012 through the Cyprus eddy region. Horizontal axis is in kilometers from the western edge of the box in Fig. 1. 
Ocean Sci. Discuss., doi:10.5194/os-2016-43, 2016

Manuscript under review for journal Ocean Sci.

Published: 28 June 2016

(c) Author(s) 2016. CC-BY 3.0 License.

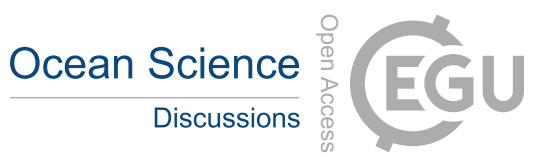

(c) $\underset{\mathrm{BY}}{\mathrm{B}}$

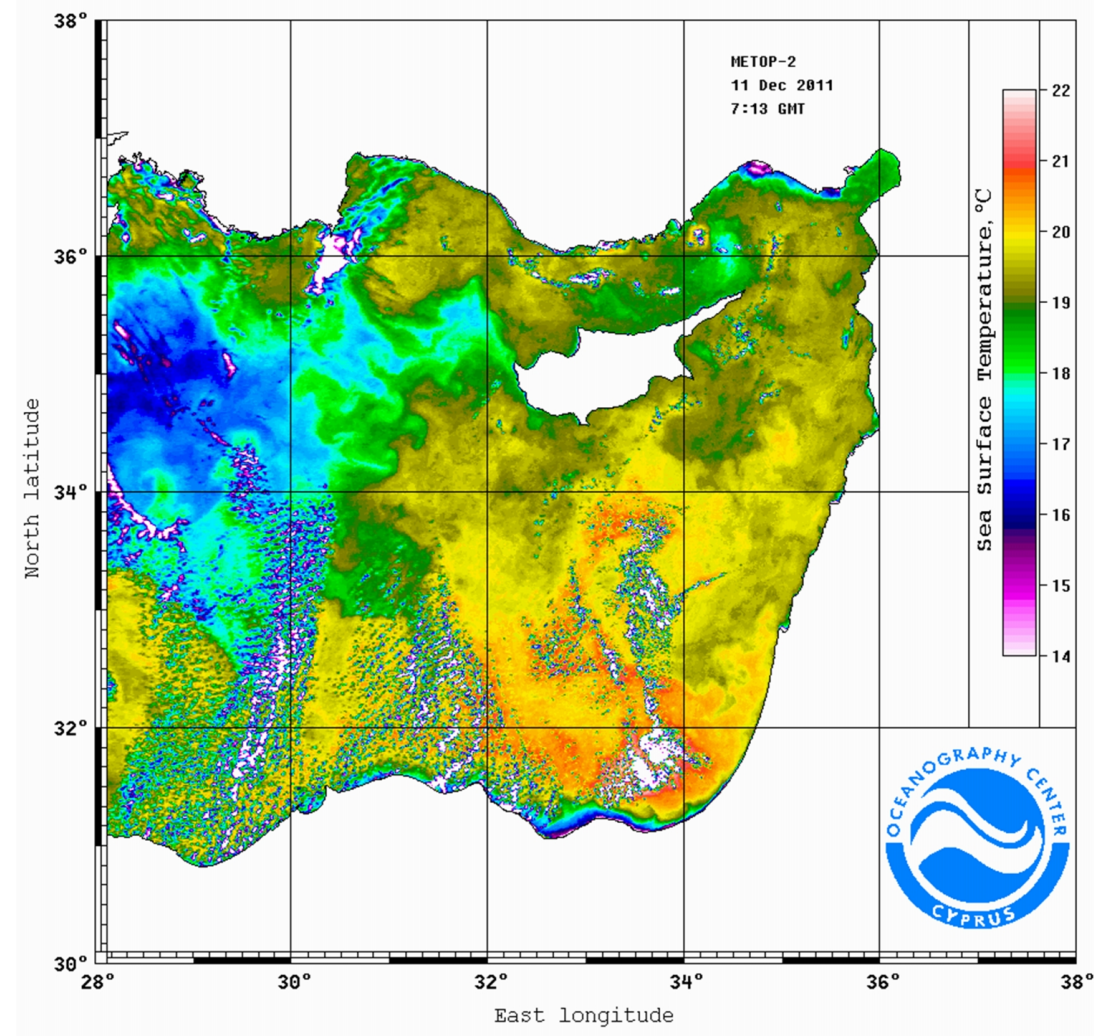

Figure 5. Remotely-sensed instantaneous sea surface temperature: on 11 December 2011. 
Ocean Sci. Discuss., doi:10.5194/os-2016-43, 2016

Manuscript under review for journal Ocean Sci.

Published: 28 June 2016

(c) Author(s) 2016. CC-BY 3.0 License.

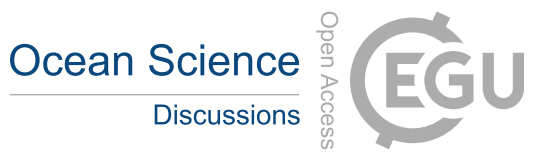

(c)
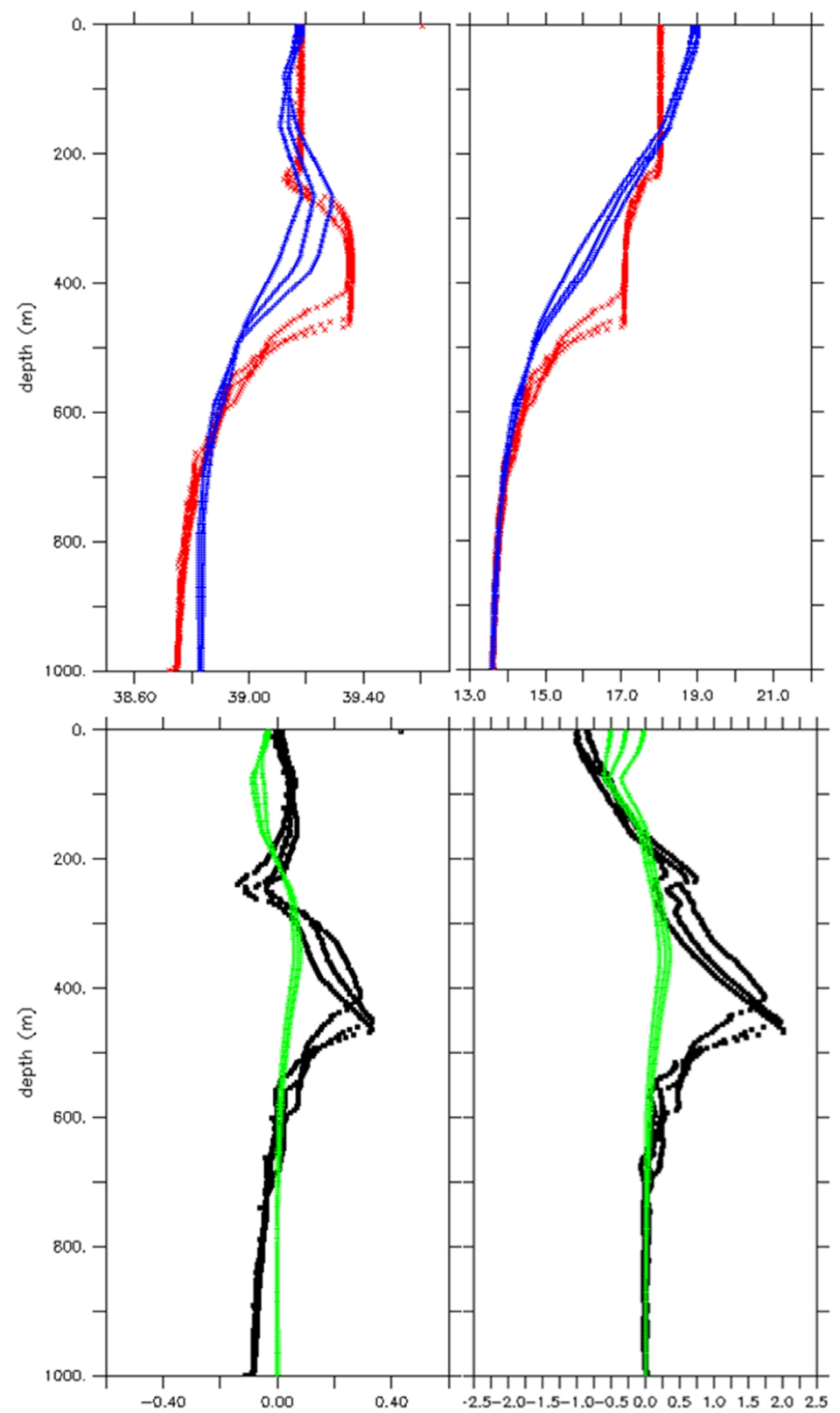

Figure 6. Profiles of model (blue) and glider (red) temperature(left) and salinity (right) for day 49 (23 January 2012) (top), used to calculate the respective misfits (black) and corrections (green) on day 50 (bottom). Note that the corrections are 3-D fields, and only the profile through the glider location is shown here. 
Ocean Sci. Discuss., doi:10.5194/os-2016-43, 2016

Manuscript under review for journal Ocean Sci.

Published: 28 June 2016

(c) Author(s) 2016. CC-BY 3.0 License.

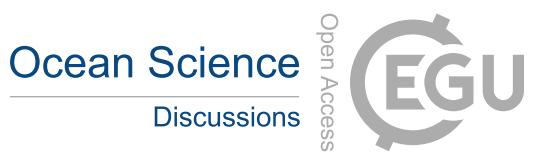

(c) (1)

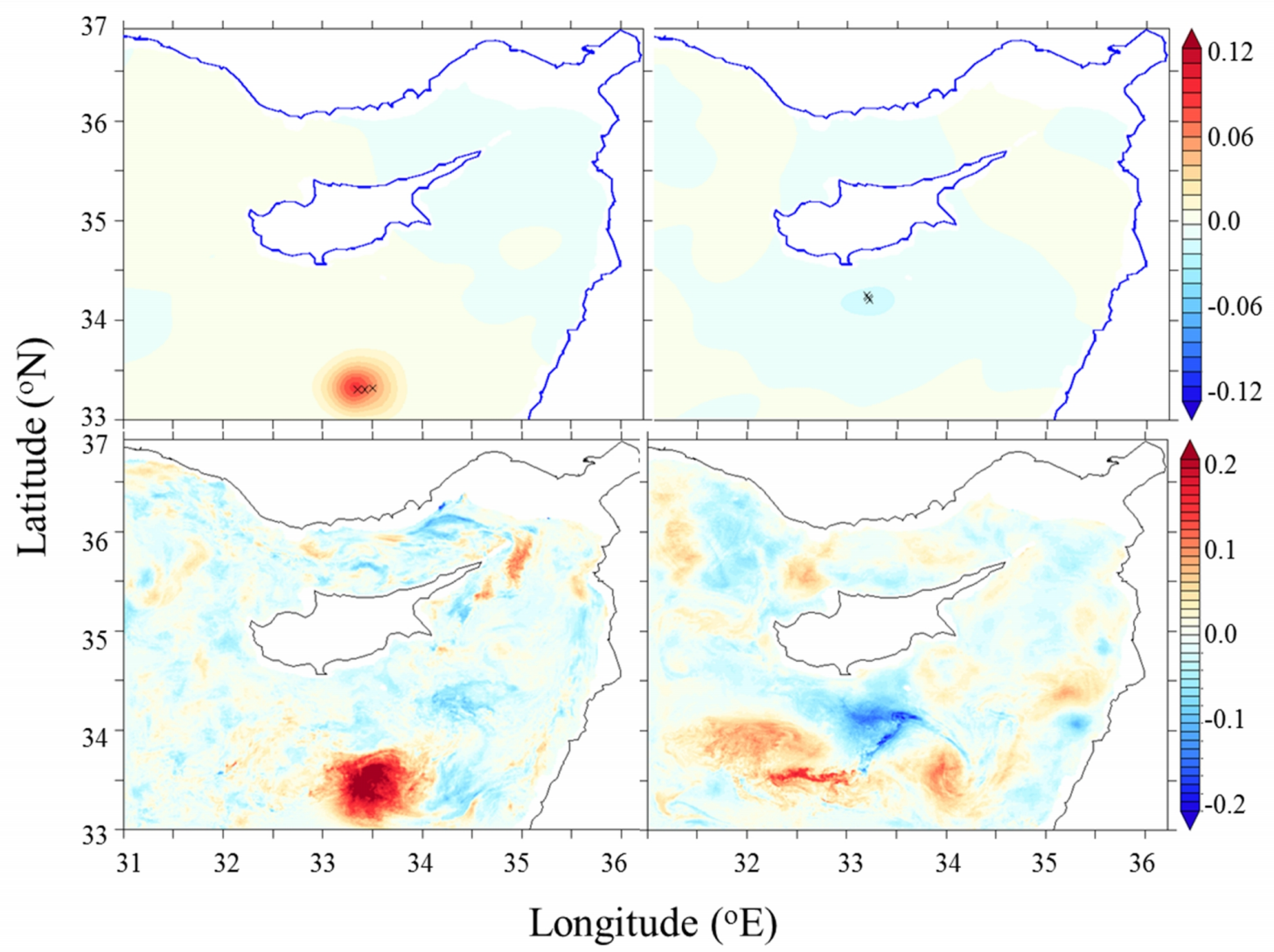

Figure 7. Corrections to salinity and glider profile locations (symbol x) for day 49 (23 January 2012) and day 174 (27 May 2012 ) at depth $360 \mathrm{~m}$ only. Difference in salinity at $360 \mathrm{~m}$ between the data assimilative run and control run for day 50 (left) and day 175 5 (right). The difference is identically zero at day 0. 
Ocean Sci. Discuss., doi:10.5194/os-2016-43, 2016

Manuscript under review for journal Ocean Sci.

Published: 28 June 2016

(c) Author(s) 2016. CC-BY 3.0 License.

(c) $\underset{\mathrm{BY}}{(i)}$

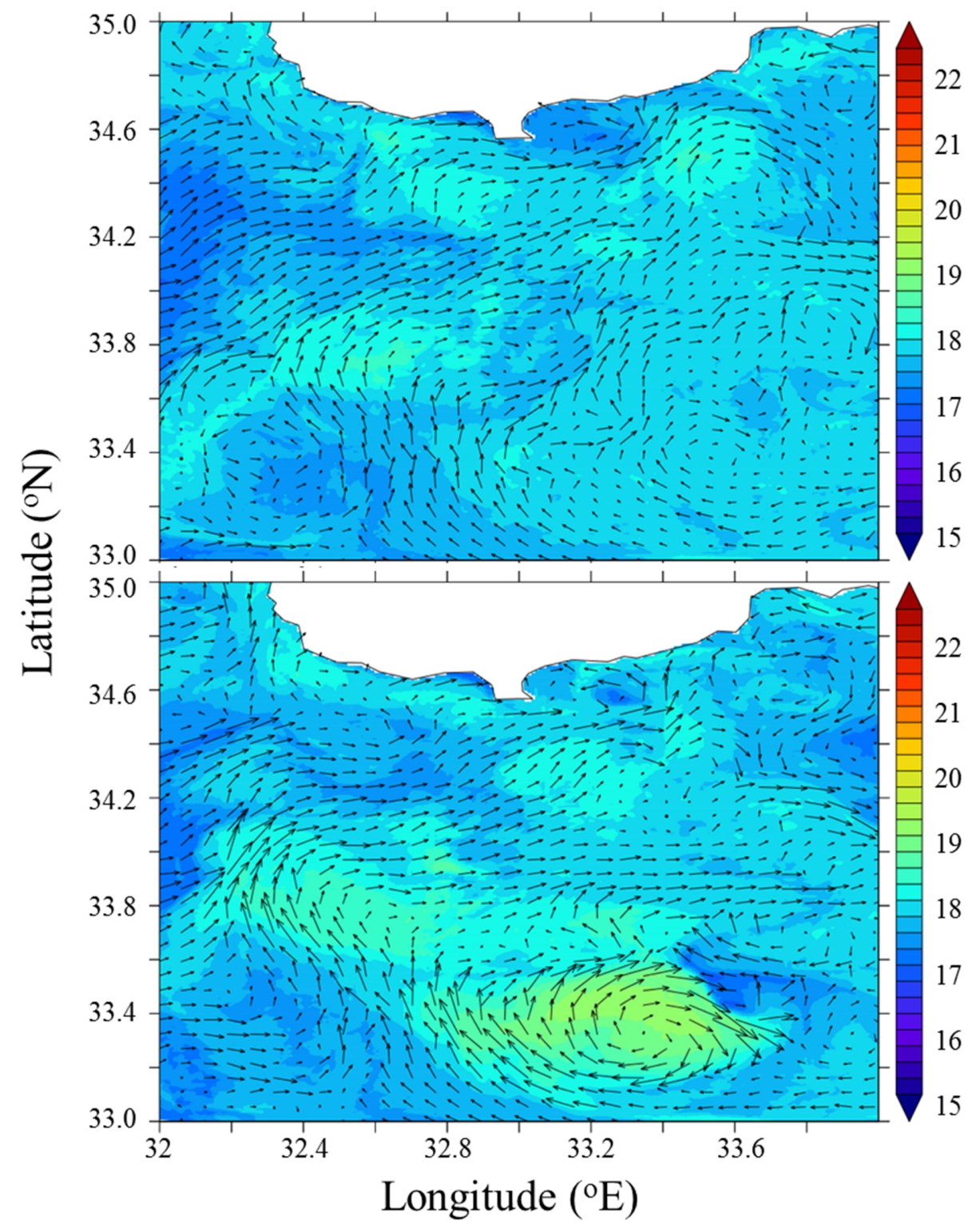

Figure 8.Current direction and Temperature at $1 \mathrm{~m}$ for day 50 (24 January 2012) for control run (top) and data assimilative run (bottom). Region of Cyprus eddy is $33.5^{\circ} \mathrm{N}, 33.5^{\circ} \mathrm{E}$. 
Ocean Sci. Discuss., doi:10.5194/os-2016-43, 2016

Manuscript under review for journal Ocean Sci.

Published: 28 June 2016

(c) Author(s) 2016. CC-BY 3.0 License.
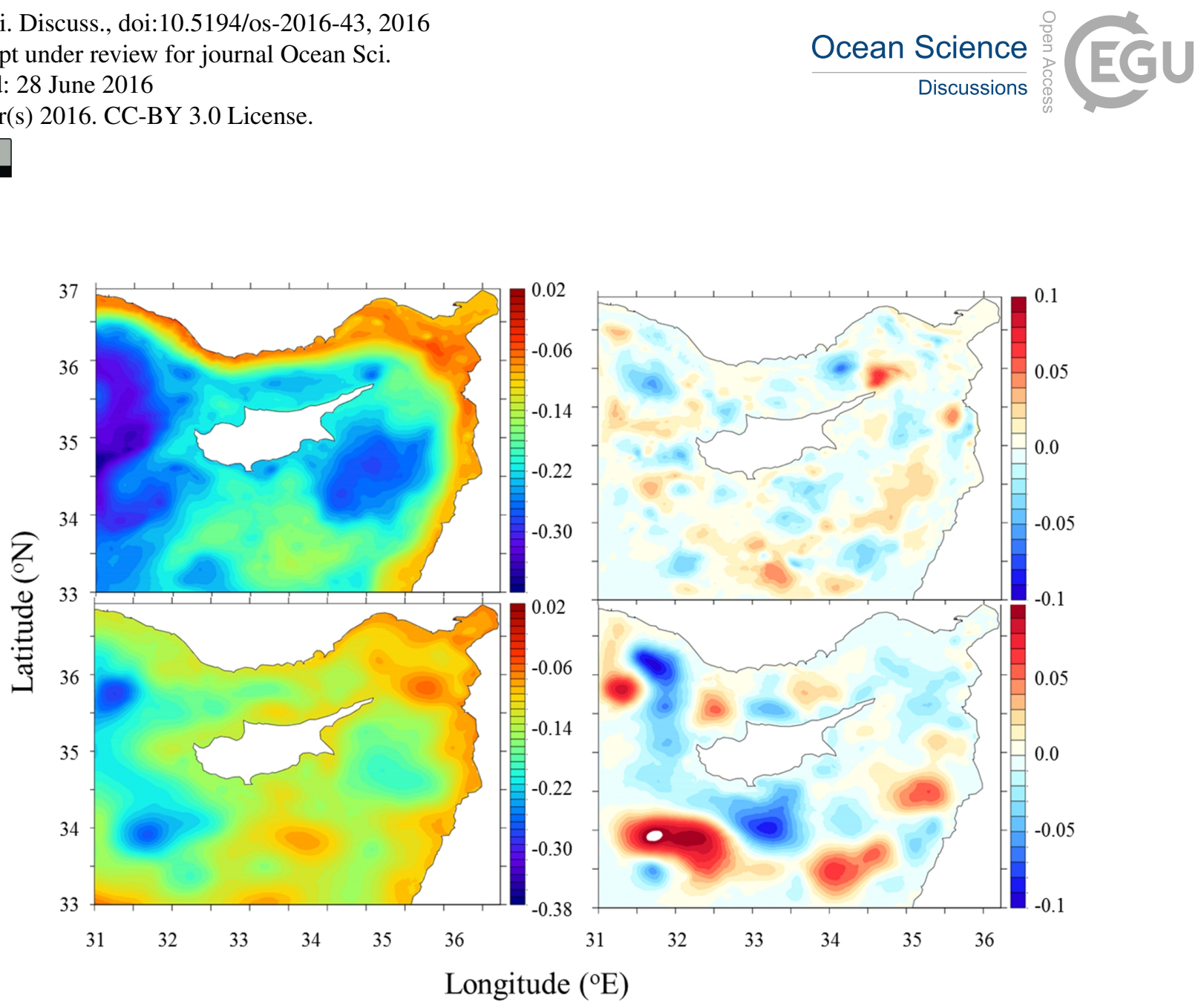

Figure 9. Sea level from CYCOM data assimilative run (left) and difference field with control run (d/a-control) (right) for 24 January 2012 (day 50, top), and 28 May 2012 (day 175, bottom). Day 0 was 6 December 2011. The same scales are used for both 5 periods. 
Ocean Sci. Discuss., doi:10.5194/os-2016-43, 2016

Manuscript under review for journal Ocean Sci.

Published: 28 June 2016

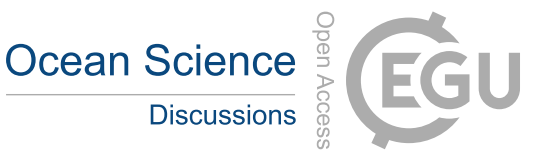

(c) Author(s) 2016. CC-BY 3.0 License.

(c) (i)

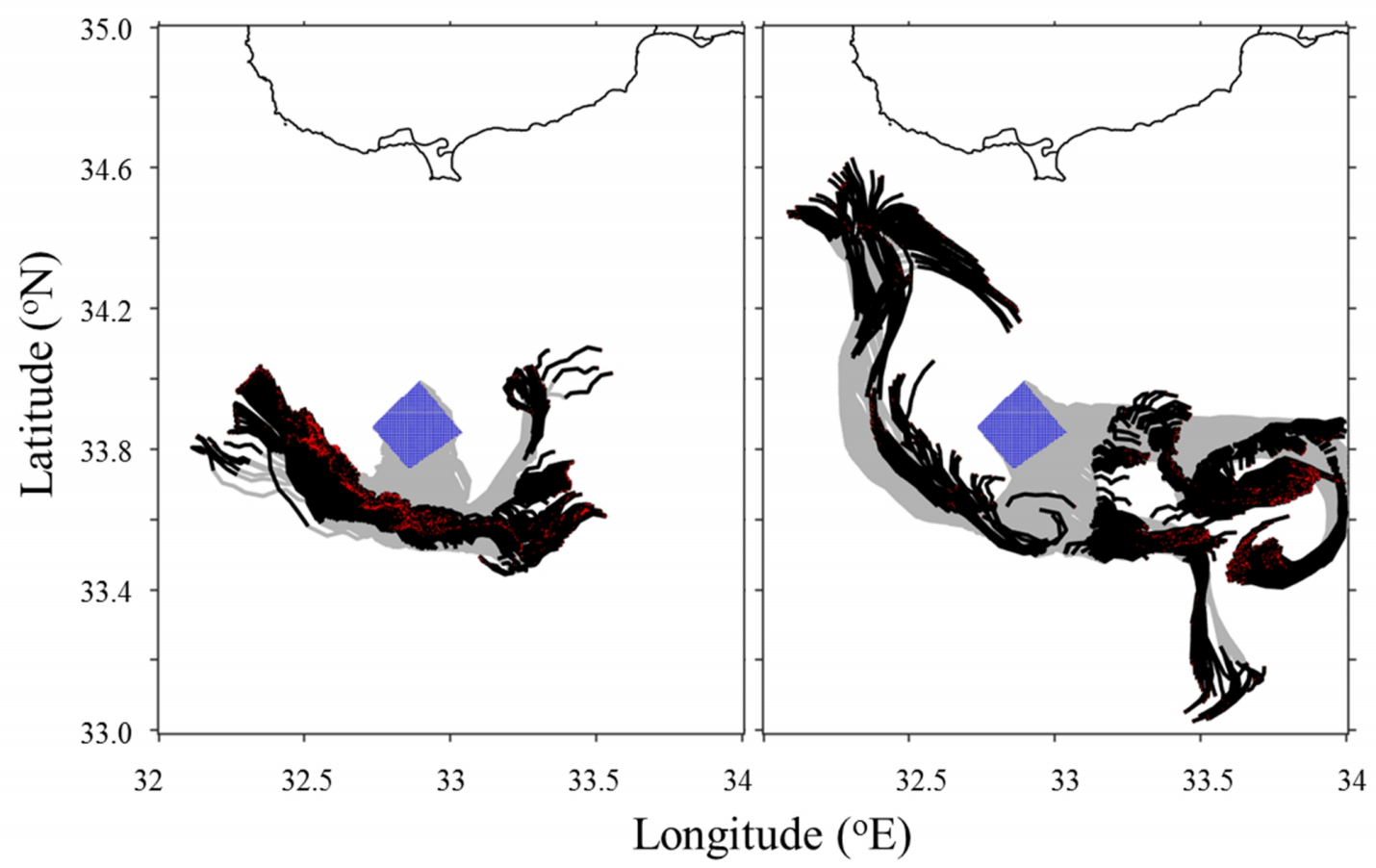

Figure 10. Lagrangian trajectories of particles driven by the model currents for control (left) and d/a (right) runs from 21 5 January, 2012, 6:00 until 28 January, 2012, at 18:00. 
Ocean Sci. Discuss., doi:10.5194/os-2016-43, 2016

Manuscript under review for journal Ocean Sci.

Published: 28 June 2016

(c) Author(s) 2016. CC-BY 3.0 License.

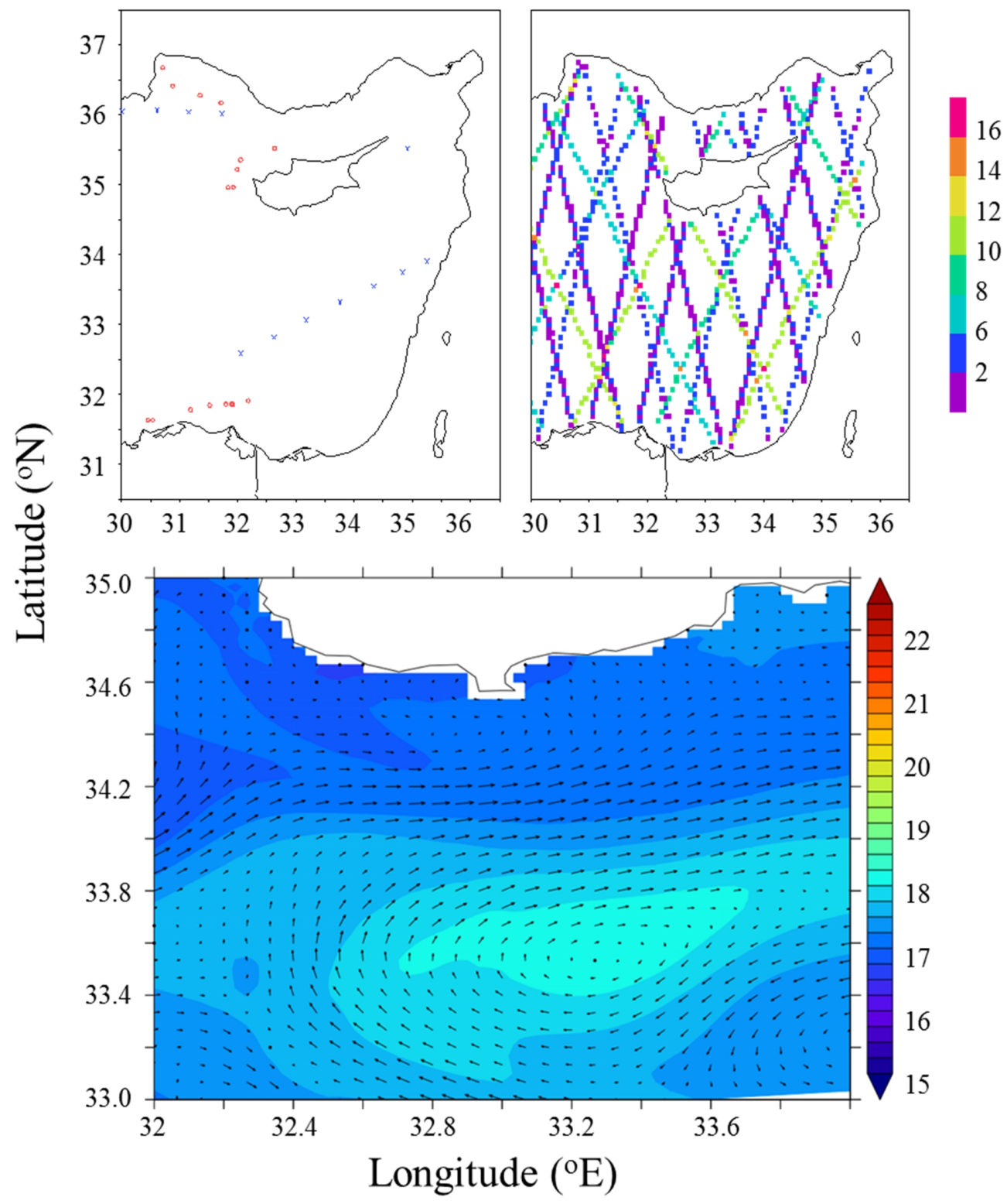

Figure 11. Data assimilated by the MFS system during the study: XBT (crosses, left) and ARGO float (circles, left), and SLA tracks (right). ALERMO surface currents and temperature for 24 January 2012 (bottom) as in Fig. 8. 
Ocean Sci. Discuss., doi:10.5194/os-2016-43, 2016

Manuscript under review for journal Ocean Sci.

Published: 28 June 2016

(c) Author(s) 2016. CC-BY 3.0 License.

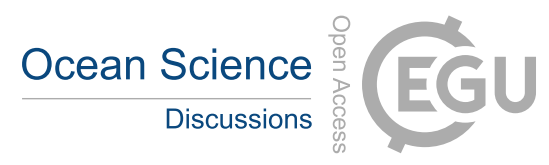

(c) (i)

Tables

Table 1. RMS differences between glider temperature and salinity observations and model fields before assimilation.

\begin{tabular}{lll}
\hline & RMS & \% reduction \\
\hline T-control & 2.09 & \\
T-d/a & 1.78 & $15 \%$ \\
S-control & 0.405 & \\
S-d/a & 0.355 & $13 \%$ \\
\hline
\end{tabular}

5 